\title{
The Implementation of Sort, Set in Order, Shine, Standardize, and Sustain as Occupational Accident Preventions at PT X
}

\author{
Penerapan Ringkas, Rapi, Resik, Rawat, Rajin Sebagai Upaya Pencegahan \\ Kecelakaan Kerja di PT X
}

\author{
Bayu Adi Radityo \\ PT Kelola Mina Laut \\ Jalan KIG Raya Selatan Kav. C-5, Kawasan Industri Gresik, Gresik, East Java 61121, Indonesia
}

\begin{abstract}
Introduction: The implementation of qualified sort, set in order, shine, standardize, and sustain (5S) is a significant factor to prevent the occurrence of occupational accidents in companies with a high-risk level of occupational accidents, such as being exposed to falling objects or tripped with objects, especially in departments that handle goods or materials. This research aims to identify the enactment of $5 \mathrm{~S}$ as occupational accidents preventions in the logistic department at PT. X. Methods: This research is descriptive-analytic research which describes the company policy regarding the employment of $5 \mathrm{~S}$ and the characteristics of the workers in the logistic department at PT. X. Moreover, this research also intends to analyze the strength of the relationship between the workers' characteristics based on the correlation coefficient value by using the cross-sectional approach. The data is in the form of secondary data obtained by using questionnaires and interview. Results: It has been noticed that there is a qualified policy regarding the implementation of $5 \mathrm{R}$ in the form of technical instructions and the SOP of the company that has been well-enacted. Majority of the workers in the logistic department at PT. X is between 15-30 years old with high school educational attainment and has been serving in the company for $<6$ years. It is also perceived that all workers in the logistic department have a good 5S understanding level and good attitudes toward the implementation of 5R. However, there is a difference in the direction of the relationship of the variables analyzed; one is a negative relationship while the other is a positive relationship. Conclusion: It can be affirmed that PT. $\mathrm{X}$ has implemented 5S in a good way, seen from the understanding level of the workers regarding 5S or the attitude of the workers in implementing 5S, particularly in the logistic department. This is also proven by the company policy on the enactment of $5 \mathrm{~S}$ that has been well-carried out.
\end{abstract}

Keywords: 5S implementation, logistic, occupational accidents

\begin{abstract}
ABSTRAK
Pendahuluan: Penerapan ringkas, rapi, resik, rawat, rajin (5R) yang baik merupakan faktor penting dalam mencegah kecelakaan kerja pada perusahaan yang mayoritas memiliki risiko kecelakaan kerja di bagian penangan barang atau bahan seperti terkena benda-benda yang jatuh atau tersandung dengan benda di tempat kerja. Penelitian ini bertujuan untuk mengidentifikasi penerapan 5R sebagai upaya pencegahan kecelakaan kerja di bagian logistic PT. X. Metode: Penelitian ini bersifat deskriptif dan analalitik, yaitu menggambarkan kebijakan perusahaan mengenai penerapan $5 R$ dan karakteristik tenaga kerja di bagian logistic PT. X serta menganalisis kuat hubungan karakteristik tenaga kerja berdasarkan nilai koefisien korelasi dengan pendekatan cross-sectional. Pengumpulan data menggunakan data sekunder, kuesioner, dan wawancara. Hasil: Hasil penelitian menunjukkan bahwa terdapat kebijakan di perusahaan mengenai penerapan $5 R$ dalam bentuk petunjuk teknis dan SOP perusahaan yang telah berjalan dengan baik. Mayoritas tenaga kerja di bagian logistic PT. X memiliki usia 15-30 tahun dengan tingkat pendidikan rata-rata SMA/SMK serta masa kerja selama $<6$ tahun. Seluruh tenaga kerja di bagian logistic memiliki pengetahuan $5 R$ dan sikap tenaga kerja terhadap penerapan $5 R$ dalam kategori baik. Terdapat perbedaaan arah hubungan antara bagian logistic dengan kondisi yang satu negatif yang lainnya positif. Simpulan: PT. X telah melaksanakan penerapan 5R secara baik, baik pada pengetahuan 5R maupun sikap tenaga kerja terhadap penerapan $5 R$ yang dimiliki oleh tenaga kerja di bagian logistic PT. X. Hal itu dibuktikan dengan kebijakan perusahaan berhubungan dengan penerapan 5R yang juga telah dilaksanakan dengan baik.Kata kunci: keluhan muskuloskeletal, Nordic Body Map, pekerja injection, postur kerja, Rapid Upper Limb Assessement
\end{abstract}

Kata kunci: logistic, kecelakaan kerja, penerapan 5R

(C2019 IJOSH All right reserved. Open access under CC BY NC-SA license doi: 10.20473/ijosh.v8i3.2019. 292-301 Received June 23, 2018, received in revised form February 07, 2019, Accepted November 04, 2019, Published: December 2019 
Author for Correspondence:

Bayu Adi Radityo

Email: bayu.adier@gmail.com

Telephone: +62885231968604

\section{INTRODUCTION}

Ministry of Manpower and Transmigration (2003) has specified that every labor has a right to obtain protection for occupational safety and health to realize optimal work productivity with efforts to implement occupational safety and health. In general, the objectives of occupational safety and health are to promote health and to ensure that the labors obtain a high level of physical, mental, and socio-economic rights.

Referring to the data of National Social Security (2016), until the end of 2015, there were 105,182 reported cases on occupational accidents. Furthermore, heavy accidents resulting in death were reported as many as 2,375 cases out of the total accidents In addition, based on the data of the International Labour Organization (2013), 1 labor died every 15 seconds due to occupational accidents, while 160 labors suffered from occupational diseases. In the previous year, ILO recorded that the high number of the death case was caused by occupational accidents and occupational diseases, which reached a total of 2 million cases every year.

One of the endeavors to enhance occupational safety and health is by implementing 5S (Seiri, Seiton, Seiso, Seiketsu, and Shitsuke), or Sort, Set in order, Shine, Standardize, and Sustain (5S). A good implementation of $5 \mathrm{~S}$ is alleged as an important factor in preventing occupational accidents, especially in companies where the majority of the workers are involved in the processes of handling goods and materials, exposed to falling objects, or been in contact with goods in a workplace.

The implementation of $5 \mathrm{~S}$ is portrayed through saving the work area, saving time in searching for goods, and being faster in identifying technical issues on the machines (Pranasution, 2015). Rochmanto (2015) conducted research which discovered that the implementation of 5S at PT Kutai Timber Indonesia (KTI) could prevent the risk of occupational safety and health by identifying the potential hazards and the controls toward those hazards. In addition, Sandika (2013) in their research concluded that the implementation of $5 \mathrm{~S}$ could expedite production, provide the convenience, and maintain the cleanness of the working environment, as well as create good performance character and disciplined habit of the workers.

The logistic department at PT $\mathrm{X}$ is the department that receives materials needed for the upcoming projects, orders the materials needed for the projects, provides construction tools if needed, performs materials and products checking before shipped, and is responsible for the product shipping. The cluttered arrangement of the materials is markedly a factor that may cause the occurrence of occupational accidents, for example, tripped by the materials or being exposed to falling materials. Besides, this kind of arrangement can also trigger a decrease in work productivity due to a long time needed in searching for materials. Hence, the implementation of $5 \mathrm{~S}$ can be used as one endeavor to rearrange the materials to decrease the probability of occupational accidents by shortening the time in materials searching.

\section{METHODS}

This research is observational research that applies the cross-sectional design, which was completed through descriptive-analytic field research. The data was collected from JanuaryApril 2018 in the logistic department at PT X. The sampling was completed by applying the total sampling technique to all 25 workers in the logistic department at PT X. The variables analyzed in this research were the age, educational background, years of service, $5 \mathrm{~S}$ understanding level, and attitudes toward $5 \mathrm{~S}$ implementation.

The data were collected through questionnaires. Then, the data were analyzed by using tables, narration, and cross-tabulation methods, particularly in the data presentation and the elucidation of the results. Meanwhile, according to Sugiyono (2013), the analysis of the strength of the correlation between variables was carried out by using Spearman's correlation test, which generated the correlation coefficient value. The strength of the correlation is presented in Table 1.

\section{RESULTS}

\section{Company's Policy on the Implementation of 5S at PT X}

PT X has implemented 5S as one of the technical instructions and standard operational procedures (SOP) that have to be performed in 
accordance with the $\mathrm{SD} / \mathrm{X}-01$ document concering 5S Control. The document described the control procedures, for instance, management commitment, $5 \mathrm{~S}$ organizational structure, $5 \mathrm{~S}$ area, $5 \mathrm{~S}$ working programs, $5 \mathrm{~S}$ implementation programs, $5 \mathrm{~S}$ evaluation activities, $5 \mathrm{~S}$ follow-up programs, and $5 \mathrm{~S}$ basic explanation. The policy on the occupational safety and health of the company contributes to the endeavor to decrease the risk of occupational safety and health as well as to provide the worker's safety and convenience workplace.

\section{Age}

The age in this research is the life span of the workers calculated from the time they were born

Table 1. Correlation Coefficient Value

\begin{tabular}{cc}
\hline Correlation Coefficient & Relationship Strength \\
\hline $0,00-0,19$ & Very weak \\
$0,20-0,39$ & Weak \\
$0,40-0,59$ & Moderate \\
$0,60-0,79$ & Strong \\
$0,80-1,00$ & Very strong \\
\hline
\end{tabular}

Table 2. The Distribution of the Workers in the Logistic Department at PT X based on the Age in 2018

\begin{tabular}{ccc}
\hline \multirow{2}{*}{ Age (years old) } & \multicolumn{2}{c}{ Logistic Department } \\
\cline { 2 - 3 } & Frequency (n) & Percentage (\%) \\
\hline $15-30$ & 11 & 44 \\
$31-45$ & 9 & 36 \\
$46-60$ & 5 & 20 \\
$>60$ & 0 & 0 \\
\hline Total & 25 & 100 \\
\hline
\end{tabular}

Table 3. The Distribution of the Workers in the Logistic Department at PT X based on the Educational Background in 2018

\begin{tabular}{ccc}
\hline \multirow{2}{*}{$\begin{array}{c}\text { Educational } \\
\text { Attainment }\end{array}$} & \multicolumn{2}{c}{ Logistic Department } \\
\cline { 2 - 3 } & Frequency (n) & Percentage (\%) \\
\hline Elementary School & 0 & 0 \\
Middle School & 0 & 0 \\
High School & 19 & 76 \\
Higher Education & 1 & 4 \\
Bachelor's Degree & 5 & 20 \\
\hline Total & 25 & 100 \\
\hline
\end{tabular}

until the time this research was conducted. Table 2 shows the distribution of the workers in the logistic department at PT X based on the age group. The table displays that most of the workers who were 11 people (44\%) belong to the age group of $15-30$ years old. Additionally, based on the table, it can be perceived that all workers are still in productive age.

\section{Educational Attainment}

The educational background of this research refers to the highest level of education that has been completed by the workers or the respondents. Table 3 presents the distribution of the workers in the logistic department at PT X based on the educational background. It is shown that the group of high school-graduates consists of almost all of the workers, which is as many as 19 people $(76 \%)$.

\section{Years of Service}

Years of service referred to in this research is the working time span calculated from the time the workers started working in the logistic department until the time when this research was carried out. The data on the years of service of the workers as presented in Table 4 discloses that the greater part of the workers, which is as many as 15 people $(60 \%)$, had served for $<6$ years in the company.

Table 4. The Distribution of the Workers in the Logistic Department at PT X based on the Years of Service in 2018

\begin{tabular}{ccc}
\hline \multirow{2}{*}{$\begin{array}{c}\text { Years of Service } \\
\text { (years) }\end{array}$} & \multicolumn{2}{c}{ Logistic Department } \\
\cline { 2 - 3 } & Frequency (n) & Percentage (\%) \\
\hline$<6$ & 15 & 60 \\
$6-10$ & 5 & 20 \\
$>10$ & 5 & 20 \\
\hline Total & 25 & 100 \\
\hline
\end{tabular}

Table 5. The Distribution of the Workers in the Logistic Department at PT X based on the 5S Understanding Level in 2018

\begin{tabular}{ccc}
\hline $\mathbf{5 S}$ & \multicolumn{2}{c}{ Logistic Department } \\
\cline { 2 - 3 } $\begin{array}{c}\text { Understanding } \\
\text { Level }\end{array}$ & Frequency (n) & Percentage(\%) \\
\hline Lack & 0 & 0 \\
Adequate & 0 & 0 \\
Good & 25 & 100 \\
\hline Total & 25 & 100 \\
\hline
\end{tabular}




\section{S Understanding Level}

The 'understanding' signified in this research is the workers' understanding of the 5S. From the data collection, it was noticed that the workers in the logistic department at PT X had a good understanding level on $5 \mathrm{~S}$, as displayed in Table 5.

\section{Workers' Attitudes toward 5S Implementation}

The workers' attitudes toward $5 \mathrm{~S}$ implementation can be seen through the action taken when the workers encountered certain conditions related to 5S. Table 6 shows the distribution of the workers' attitudes toward $5 \mathrm{~S}$ implementation in the logistic department at PT X. Based on the data collected, it can be seen that all 25 workers $(100 \%)$ considered have a good-attitude, which implies that the workers have already obeyed the company regulations regarding the implemented $5 \mathrm{~S}$.

The Analysis of the Strength of the Correlation between the $5 \mathrm{~S}$ Understanding Level and the Workers' Attitudes toward $5 \mathrm{~S}$ implementation

By referring to the Spearman's correlation test presented in Table 7 below, it can be perceived that the test obtained the correlation coefficient value of 0.383 . This implies that the variables have a positive

Table 6. The Distribution of the Workers in the Logistic Department at PT X based on the Attitudes toward 5S implementation in 2018

\begin{tabular}{ccc}
\hline \multirow{2}{*}{$\begin{array}{c}\text { Lttitudes toward } \\
\text { 5S }\end{array}$} & \multicolumn{2}{c}{ Logistic Department } \\
\cline { 2 - 3 } Brequency (n) & Percentage (\%) \\
\hline Bad & 0 & 0 \\
Good enough & 0 & 0 \\
Good & 25 & 100 \\
\hline Total & 25 & 100 \\
\hline
\end{tabular}

direction with low correlation strength. In other words, there is a directional correlation between the $5 \mathrm{~S}$ understanding level and the attitudes toward $5 \mathrm{~S}$ implementation in the logistic department at PT X, or else, the higher the understanding level, the better the attitude.

The Analysis of the Strength of the Correlation between the Age and 5S Understanding Level of the Workers

Spearman's correlation test carried out to the data resulted in the correlation coefficient value as much as 0.106 (Table 8 ). Thus, the value suggests that there is a positive course, yet the correlation between the two variables is very low. Additionally, it can be stated that there is a directional correlation between the two variables, where the older age is in line with the higher understanding level of $5 \mathrm{~S}$.

The Analysis of the Strength of the Correlation between the Age and the Workers' Attitudes toward 5S Implementation

In Table 9, the correlation coefficient value obtained from Spearman's correlation test was 0.326 , which implies that the correlation showed a positive direction with a weak correlation. In other words, there is a directional correlation between variables, where the older the workers, the better the attitudes toward $5 \mathrm{~S}$ implementation.

\section{The Analysis of the Strength of the Correlation between the Educational Background and $5 \mathrm{~S}$ Understanding Level}

The result of Spearman's correlation test displayed in Table 10 showed the correlation coefficient value of -0.070 . It can be stated that from the result, there is a negative direction with a weak correlation between variables. Or else, it can be assumed that the higher the educational background

Table 7. The Strength of the Correlation between the 5S Understanding Level and the Workers' Attitudes toward 5S Implementation in the Logistic Department at PT X in 2018

\begin{tabular}{|c|c|c|c|c|c|c|c|c|}
\hline \multirow{3}{*}{$\begin{array}{c}\text { 5S Understanding } \\
\text { Level }\end{array}$} & \multicolumn{6}{|c|}{ Attitudes toward 5S } & \multirow{2}{*}{\multicolumn{2}{|c|}{ Total }} \\
\hline & \multicolumn{2}{|c|}{ Bad } & \multicolumn{2}{|c|}{ Good enough } & \multicolumn{2}{|c|}{ Good } & & \\
\hline & n & $\%$ & n & $\%$ & n & $\%$ & $\mathbf{N}$ & $\%$ \\
\hline Lack & 0 & 33.33 & 0 & 33.33 & 0 & 33.33 & 0 & 100 \\
\hline Adequate & 0 & 33.33 & 0 & 33.33 & 0 & 33.33 & 0 & 100 \\
\hline Good & 0 & 0 & 0 & 0 & 25 & 100 & 25 & 100 \\
\hline \multicolumn{7}{|c|}{ Correlation Coefficient Value } & \multicolumn{2}{|c|}{0.383} \\
\hline
\end{tabular}


Table 8. The Strength of the Correlation between the Age and 5S Understanding Level in the Logistic Department at PT X in 2018

\begin{tabular}{|c|c|c|c|c|c|c|c|c|}
\hline \multirow{3}{*}{$\begin{array}{l}\text { Age (years } \\
\text { old) }\end{array}$} & \multicolumn{6}{|c|}{ 5S Understanding Level } & \multirow{2}{*}{\multicolumn{2}{|c|}{ Total }} \\
\hline & \multicolumn{2}{|c|}{ Lack } & \multicolumn{2}{|c|}{ Adequate } & \multicolumn{2}{|c|}{ Good } & & \\
\hline & $\mathbf{n}$ & $\%$ & n & $\%$ & $\mathbf{n}$ & $\%$ & $\mathbf{N}$ & $\%$ \\
\hline $15-30$ & 0 & 0 & 0 & 0 & 11 & 100 & 11 & 100 \\
\hline $31-45$ & 0 & 0 & 0 & 0 & 9 & 100 & 9 & 100 \\
\hline $46-60$ & 0 & 0 & 0 & 0 & 5 & 100 & 5 & 100 \\
\hline \multirow[t]{2}{*}{$>60$} & 0 & 33.33 & 0 & 33.33 & 0 & 33.33 & 0 & 100 \\
\hline & \multicolumn{5}{|c|}{ Correlation Coefficient Value } & & 0.106 & \\
\hline
\end{tabular}

Table 9. The Strength of the Correlation between the Age and the Workers' Attitudes toward 5S Implementation in the Logistic Department at PT X in 2018

\begin{tabular}{|c|c|c|c|c|c|c|c|c|}
\hline \multirow{3}{*}{ Age (years old) } & \multicolumn{6}{|c|}{ Attitudes toward 5S } & \multirow{2}{*}{\multicolumn{2}{|c|}{ Total }} \\
\hline & \multicolumn{2}{|c|}{ Bad } & \multicolumn{2}{|c|}{ Good Enough } & \multicolumn{2}{|c|}{ Good } & & \\
\hline & $\mathbf{n}$ & $\%$ & $\mathbf{n}$ & $\%$ & $\mathbf{n}$ & $\%$ & $\mathbf{N}$ & $\%$ \\
\hline $15-30$ & 0 & 0 & 0 & 0 & 11 & 100 & 11 & 100 \\
\hline $31-45$ & 0 & 0 & 0 & 0 & 9 & 100 & 9 & 100 \\
\hline $46-60$ & 0 & 0 & 0 & 0 & 5 & 100 & 5 & 100 \\
\hline$>60$ & 0 & 33.33 & 0 & 33.33 & 0 & 33.33 & 0 & 100 \\
\hline \multicolumn{7}{|c|}{ Correlation Coefficient Value } & \multicolumn{2}{|c|}{0.326} \\
\hline
\end{tabular}

Table 10. The Strength of the Correlation between the Educational Background and 5S Understanding Level of the Workers of the Logistic Department at PT X in 2018

\begin{tabular}{|c|c|c|c|c|c|c|c|c|}
\hline \multirow{3}{*}{$\begin{array}{l}\text { Educational } \\
\text { Attainment }\end{array}$} & \multicolumn{6}{|c|}{ 5S Understanding Level } & \multirow{2}{*}{\multicolumn{2}{|c|}{ Total }} \\
\hline & \multicolumn{2}{|c|}{ Lack } & \multicolumn{2}{|c|}{ Adequate } & \multicolumn{2}{|c|}{ Good } & & \\
\hline & $\mathbf{n}$ & $\%$ & $\mathbf{n}$ & $\%$ & n & $\%$ & $\mathbf{N}$ & $\%$ \\
\hline Elementary School & 0 & 33.33 & 0 & 33.33 & 0 & 33.33 & 0 & 100 \\
\hline Middle School & 0 & 33.33 & 0 & 33.33 & 0 & 33.33 & 0 & 100 \\
\hline High School & 0 & 0 & 0 & 0 & 19 & 100 & 19 & 100 \\
\hline Higher Education & 0 & 0 & 0 & 0 & 1 & 100 & 1 & 100 \\
\hline Bachelor's Degree & 0 & 0 & 0 & 0 & 5 & 100 & 5 & 100 \\
\hline \multicolumn{7}{|c|}{ Correlation Coefficient Value } & \multicolumn{2}{|c|}{-0.070} \\
\hline
\end{tabular}

of a worker in the logistic department at PT X, the worse the $5 \mathrm{~S}$ understanding level, and vice versa.

\section{The Analysis of the Strength of the Correlation between the Educational Background and the Workers' Attitudes toward 5S implementation}

Table 11 presents the correlation coefficient value of - 0.116 attained from Spearman's correlation test. This shows that both variables have a negative direction with a very weak correlation. Furthermore, this means that there is an oppositional correlation between the educational background and the workers' attitudes toward 5S implementation in the logistic department at PT X. Needless to say, it is affirmed that the higher the educational background, the worse the attitude, and vice versa.

The Analysis of the Strength of the Correlation between the Years of Service and $5 \mathrm{~S}$ Understanding Level

Spearman's correlation test carried out to both variables showed the correlation coefficient value of 0.016 , as shown in Table 12. Consequently, this can be perceived that there is a positive and directional 
Table 11. The Strength of the Correlation between the Educational background and the Workers' Attitudes toward 5S Implementation in the Logistic Department at PT X in 2018

\begin{tabular}{|c|c|c|c|c|c|c|c|c|}
\hline \multirow{3}{*}{ Educational Attainment } & \multicolumn{6}{|c|}{ Attitudes toward 5S } & \multirow{2}{*}{\multicolumn{2}{|c|}{ Total }} \\
\hline & \multicolumn{2}{|c|}{ Bad } & \multicolumn{2}{|c|}{ Good Enough } & \multicolumn{2}{|c|}{ Good } & & \\
\hline & $\mathbf{n}$ & $\%$ & $\mathbf{n}$ & $\%$ & $\mathbf{n}$ & $\%$ & $\mathbf{N}$ & $\%$ \\
\hline Elementary School & 0 & 33.33 & 0 & 33.33 & 0 & 33.33 & 0 & 100 \\
\hline Middle School & 0 & 33.33 & 0 & 33.33 & 0 & 33.33 & 0 & 100 \\
\hline High School & 0 & 0 & 0 & 0 & 19 & 100 & 19 & 100 \\
\hline Higher Education & 0 & 0 & 0 & 0 & 1 & 100 & 1 & 100 \\
\hline Bachelor's Degree & 0 & 0 & 0 & 0 & 5 & 100 & 5 & 100 \\
\hline \multicolumn{7}{|c|}{ Correlation Coefficient Value } & \multicolumn{2}{|c|}{-0.116} \\
\hline
\end{tabular}

Table 12. The Strength of the Relationship between the Years of Service and 5S Understanding Level of the Workers in the Logistic Department at PT. X in 2018

\begin{tabular}{ccccccccc}
\hline \multirow{2}{*}{$\begin{array}{c}\text { Years of } \\
\text { Service } \\
\text { (years) }\end{array}$} & \multicolumn{9}{c}{ 5S Understanding Level } & \multirow{2}{*}{ Total } \\
\cline { 2 - 7 } & $\mathbf{n}$ & $\mathbf{\%}$ & $\mathbf{n}$ & $\%$ & $\mathbf{n}$ & $\mathbf{\%}$ & $\mathbf{N}$ & $\mathbf{\%}$ \\
\hline$<6$ & 0 & 0 & 0 & 0 & 15 & 100 & 15 & 100 \\
$6-10$ & 0 & 0 & 0 & 0 & 5 & 100 & 5 & 100 \\
$>10$ & 0 & 0 & 0 & 0 & 5 & 100 & 5 & 100 \\
\hline \multicolumn{1}{c}{ Correlation Coefficient Value } \\
\hline
\end{tabular}

correlation yet a very weak correlation between variables. Thus, it can be affirmed that the longer the years of service, the better the $5 \mathrm{~S}$ understanding level.

The Analysis of the Strength of the Correlation between the Years of Service and the Workers' Attitudes toward 5S Implementation

Table 13 displays the correlation coefficient value of 0.079 based on Spearman's correlation test performed to both variables. Therefore, it can be noticed that there is a positive and directional correlation with a very weak correlation between the two variables. In other words, the longer the years of service, the better the attitudes toward $5 \mathrm{~S}$ implementation.

\section{DISCUSSION}

\section{The Company's Policy Regarding the Implementation of 5S at PT $X$}

PT X has implemented $5 \mathrm{~S}$ as one of the technical instructions and SOP regulated in the
Table 13. The Strength of the Correlation between the Years of Service and the Workers' Attitudes toward 5S implementation in the Logistic Department at PT X in 2018

\begin{tabular}{|c|c|c|c|c|c|c|c|c|}
\hline \multirow{3}{*}{$\begin{array}{l}\text { Years of } \\
\text { Service } \\
\text { (years) }\end{array}$} & \multicolumn{6}{|c|}{ Attitudes toward 5S } & \multirow{2}{*}{\multicolumn{2}{|c|}{ Total }} \\
\hline & \multicolumn{2}{|c|}{ Bad } & \multicolumn{2}{|c|}{$\begin{array}{c}\text { Good } \\
\text { Enough }\end{array}$} & \multicolumn{2}{|c|}{ Good } & & \\
\hline & n & $\%$ & $\mathbf{n}$ & $\%$ & n & $\%$ & $\mathbf{N}$ & $\%$ \\
\hline$<6$ & 0 & 0 & 0 & 0 & 15 & 100 & 15 & 100 \\
\hline $6-10$ & 0 & 0 & 0 & 0 & 5 & 100 & 5 & 100 \\
\hline$>10$ & 0 & 0 & 0 & 0 & 5 & 100 & 5 & 100 \\
\hline \multicolumn{7}{|c|}{ Correlation Coefficient Value } & \multicolumn{2}{|c|}{0.078} \\
\hline
\end{tabular}

$\mathrm{SD} / \mathrm{X}-01$ document concerning the 5S Control. This document provides guideline to all workers to control $5 \mathrm{~S}$ implementation in each working area as well as to give a bigger picture and how to implement those controls to increase productivity and to prevent occupational accidents.

In addition, the company has carried out several workshops and counselings on occupational safety and health, including $5 \mathrm{~S}$ implementation for all workers once every year for refreshing basic safety. The activities to enhance $5 \mathrm{~S}$ implementation consist of working area documentation; human resources training to handle $5 \mathrm{~S}$ implementation; $5 \mathrm{~S}$ implementation monitoring by cooperating with leaders, supervisors, coordinators, and foremen; provide cleaning equipment; as well as monthly inspection.

The success of $5 \mathrm{~S}$ implementation is determined by the support of human resources, structures, and systems. However, commitment, communication, leadership, coordination, participation, and cooperation are required to ensure that $5 \mathrm{~S}$ has been implemented properly. Moreover, the implementation 
of $5 \mathrm{~S}$ can be secured, monitored, controlled, and carried out by all workers (Osada, 1995). Regardless, the main goal of $5 \mathrm{~S}$ implementation is to maximize the occupational safety and health, which is related to the productivity increase (Kilpatrick, 2003).

\section{Age}

Based on the research completed and presented in Table 2, it was obtained that the majority of the workers were categorized in the age group of 1530 years old. All workers are in their productive age, which means that the company has workers with a maximum working capability. Furthermore, it is believed that the older someone, the more developed the mindset, which results in a better level of understanding (Budiman and Riyanto, 2013). It is in line with the research conducted by Irawan (2011) on 5S implementation in the production and administration departments at PT Calvari Abadi Unit Precast Concrete, in which some of the respondents in the production department were categorized in the age group of 15-30 years old.

\section{Educational Background}

Referring to Table 3, it was discovered that the highest educational background of the majority of the workers in the logistic department at PT X is high school-graduates. This result is similar to the research piloted by Istianti (2008) regarding $5 \mathrm{~S}$ implementation as one endeavor to prevent occupational accidents, in which some of the respondents are high school-graduates. Usually, educational background influences a person's mindset, providing that the goal of education itself is to change a person's attitudes and ability in performing an activity, for example, attitudes and ability in avoiding occupational accidents. Furthermore, it is known that one of the factors that influence the level of understanding is the educational background (Budiman and Riyanto, 2013).

\section{Years of Service}

In Table 4, it was displayed that most of the workers in the logistic department at PT X have been serving the company for $<6$ years. Another research regarding $5 \mathrm{~S}$ implementation as prevention of occupational accidents, for instance, the one carried out by Wulansari (2009), was also completed to the workers whose years of service were $<6$ years. In addition, it is affirmed that the experienced workers will be easier to recognize the working environment, accordingly, they will be more careful when working (Suma'mur, 2009).

\section{S Understanding Level}

The results of the research, especially in Table 5 , indicated that most of the workers in the logistic department at PT X had a good understanding level of $5 \mathrm{~S}$ and its implementation. Apparently, this result has resulted by the role of the Health and Safety Executive (HSE) in increasing the awareness of 5S implementation in the company. Among the efforts done by the HSE at PT X were working area documentation; human resources training to handle 5S implementation; 5S implementation monitoring by cooperating with leaders, supervisors, coordinators, and foremen; provide cleaning equipment; as well as monthly inspection.

According to Notoatmodjo (2003), knowledge or understanding level is a result of knowing, which happens after someone sensing a certain object. This sensing is performed through five human senses, namely the senses of sight, hearing, smell, taste, and touch. Nonetheless, most of human knowledge is perceived through eyes and ears. Therefore, based on the results of the research, this research is similar to the one carried out by Setyanto (2015), in which respondents were noticed to have a good $5 \mathrm{~S}$ understanding level.

\section{The Workers' Attitudes toward 5S Implementation}

From the research completed to the variables, it was obtained that almost all of the workers in the logistic department at PT X has a good attitude towards $5 \mathrm{~S}$ implementation, as displayed in Table 6 . The success of $5 \mathrm{~S}$ implementation is determined by the support of human resources, structures, and company systems. However, some obstacles that still can be discovered in $5 \mathrm{~S}$ implementation were overworkload and quickened deadlines. Consequently, these obstacles can result in a dirtier working environment since the workers focus on finishing the works in a short period of time without paying attention to $5 \mathrm{~S}$ aspects. Hence, the workers who do not pay attention to $5 \mathrm{~S}$ aspects when finishing the work were required to attend a special training and supervision by the HSE.

Nevertheless, there are additional factors affecting an individual's attitudes toward objects or stimulus, namely internal and external factors of the 
individual (Notoatmodjo, 2003). The internal factors comprise age, health, and experience. Meanwhile, the external factors cover information and molding framework. Due to those reasons, this research is in accordance with the research authored by Dewi (2013), in which some of the respondents had a good attitude towards $5 \mathrm{~S}$ implementation.

The Analysis of the Strength of the Correlation between $5 \mathrm{~S}$ Understanding Level and the Workers' Attitudes toward 5S Implementation

Spearman's correlation test in Table 7 displayed that there is a positive directional yet weak correlation between the $5 \mathrm{~S}$ understanding level and the workers' attitudes toward 5S implementation in the logistic department at PT X. In other words, it can be implied that the better the understanding level of $5 \mathrm{~S}$, the better the attitudes toward its implementation.

This research is in accordance with the research carried out by Dewi (2013), which concluded that there is a correlation between the $5 \mathrm{~S}$ understanding level and the attitudes toward $5 \mathrm{~S}$ implementation in the Technical Administration Work Unit department. However, the results are not the same as what Green proposed in Notoatmodjo (2003), which stated that knowledge is one of the most important yet inadequate factors in changing individual's attitude and the increase in knowledge does not always change individual's attitude.

\section{The Analysis of the Strength of the Correlation between the Age and $5 \mathrm{~S}$ Understanding Level}

Spearman's correlation test value showed in Table 8 implied that there is a very weak correlation between the age and $5 \mathrm{~S}$ understanding level in the logistic department at PT X, which means that there is a positive directional correlation between variables. In other words, it can be stated that the older the worker, the better the level of understanding.

Referring to ILO, the productive age ranges between 15-64 years old, while the non-productive age ranges between 0-14 and $>64$ years old, from which can be implied that all workers in the logistic department at PT X are in their productive age. The thinking, reasoning, and memorizing abilities of those who are in the productive age are better than the older, since older people undergo a decrease in physical and mental abilities (Notoatmodjo, 2007).
The Analysis of the Strength of the Correlation between the Age and the Workers' Attitudes toward 5S Implementation

The results of Spearman's correlation test displayed in Table 9 indicated that there is a weak correlation between the age and the workers' attitudes toward $5 \mathrm{~S}$ implementation. Furthermore, this also meant that there is a positive directional correlation with a weak correlation between two variables, or else, the older the worker, the better the attitudes toward $5 \mathrm{~S}$ implementation.

However, by referring to the results, this research is not in accordance with the research conducted by Septaviani (2012). In her research that focused on the factors related to $5 \mathrm{~S}$ to the workshop mechanics X in Semarang in 2012, it was obtained that the age factor did not have any correlation with $5 \mathrm{~S}$ implementation.

The Analysis of the Strength of the Correlation between the Educational Background and $5 \mathrm{~S}$ Understanding Level

The results of Spearman's correlation test presented in Table 10 indicated that there is a very weak correlation between the educational background and $5 \mathrm{~S}$ understanding level of the workers in the logistic department at PT X. The value implied a negative oppositional direction with a very weak correlation, which can be assumed that the higher the educational background of the worker, the worse the understanding level of $5 \mathrm{~S}$. Nonetheless, this result is not the same as the result in Rahmatullah (2015) research, which affirmed that the higher the educational background of the worker, the better the understanding level.

The Analysis of the Strength of the Correlation between Educational Background and the Workers' Attitudes toward 5S Implementation

Table 11 denoted that there is a very weak correlation between educational background and attitudes toward $5 \mathrm{~S}$ implementation of the workers in the logistic department at PT X. Moreover, the correlation coefficient value showed a negative direction with a very low correlation, which meant that there is an oppositional direction between the two variables. In other words, it can be stated that the higher the educational background, the worse the attitudes toward $5 \mathrm{~S}$ implementation.

Interestingly, the result of this research is the same as the one conducted by Elyanti (2017) on 
the $5 \mathrm{~S}$ attitude determinants of the grade- 3 nurses at Regional Public Hospital Pasar Rebo Jakarta in 2017. The research concluded that there is no correlation between educational background and attitudes toward 5S. Nevertheless, this is not the same as what Notoatmodjo (2003) the educational background is highly influential to the learning process and is basic knowledge for critical thinking and action toward something. Furthermore, it is also stated that the higher the educational background, the easier it is for someone to acquire new information.

\section{The Analysis of the Strength of the Correlation between the Years of Service and $5 \mathrm{~S}$ Understanding Level}

The results of Spearman's correlation test presented in Table 12, it can be seen that there is a very weak correlation between the years of service and $5 \mathrm{~S}$ understanding level of the workers in the logistic department at PT X. The correlation coefficient value implied a positive direction with a very weak correlation, which also indicated that there is a directional correlation between the two variables. Or else, it can be stated that the longer the years of service is, the better the understanding level of $5 \mathrm{~S}$ is. Moreover, it is noticed that this result is in accordance with Suma'mur (1994) claim; that the workers with the long years of service tend to experience fewer occupational accidents than the workers with shorter years of service and less talented do.

\section{The Analysis of the Strength of the Correlation between the Years of Service and the Workers' Attitudes toward 5S implementation}

It can be perceived from Table 13 that according to the Spearman correlation test, there is a very weak correlation between the years of service and the workers' attitudes toward 5S implementation in the logistic department at PT X. The value showed a positive direction with a very weak correlation, which suggested that there is a directional correlation between the two variables. In other words, it can be stated that the longer the years of service, the better the attitudes toward $5 \mathrm{~S}$ implementation.

This research is in accordance with the research conducted by Elyanti (2017) on the 5S attitude determinants of the grade- 3 nurses at Regional Public Hospital Pasar Rebo Jakarta in 2017, which showed that there is a correlation between the years of service and the attitudes toward 5S.
In addition, according to Geller (2001), years of service and working environment influence workers in performing unsafe actions.

\section{CONCLUSION}

According to the research that has been completed, it can be concluded that PT X has been implementing $5 \mathrm{~S}$ in a good way. This can be proven through the company's policy regarding occupational safety and health and $5 \mathrm{~S}$ implementation along with its programs that have been conducted continuously. All workers were discovered having a good understanding level of $5 \mathrm{~S}$ and a good attitude towards $5 \mathrm{~S}$ implementation, which implies that the realization of $5 \mathrm{~S}$ in the company is on a good track. Additionally, there has been found several factors that may increase the understanding level of $5 \mathrm{~S}$. Those factors cover workshops or counselings on occupational safety and health in a workplace, including $5 \mathrm{~S}$ implementation, briefing on the occupational safety before working, and the company's policy that is committed to the implementation of occupational safety and health.

\section{ACKNOWLEDGMENT}

The authors would like to acknowledge all workers in the logistic department at PT X who agreed to be the respondents and being cooperative during this research.

\section{REFERENCES}

Budiman and Riyanto, A. (2013) Kapita Selekta Kuesioner Pengetahuan dan Sikap dalam Penelitian Kesehatan. Jakarta: Salemba Medika. Dewi, A. M. (2013) Penerapan Program 5R sebagai Salah Satu Upaya Pencegahan Kecelakaan Kerja di Unit Kerja Administrasi Perencanaan Teknik dan di Unit Kerja Produksi Finish Mill dan Packer PT. Semen Indonesia (Persero) Tbk. Undergraduate Thesis. Surabaya: Faculty of Public Health, Universits Airlangga.

Elyanti, N. (2017) Determinan Perilaku 5R (Ringkas, Rapi, Resik, Rawat, Rajin) pada Perawat Kelas III di RSUD Pasar Rebo Jakarta Tahun 2017. Undergraduate Thesis. Jakarta: Faculty of Medicine and Health Sciences, Universitas Islam Negeri Syarif Hidayatullah.

Geller, E. S. (2001) The Psychology of Safety Handbook. 2nd edn. Boca Raton: CRC Press. 
International Labour Organization (2013) Keselamatan dan Kesehatan Kerja : Sarana untuk Produktivitas. 5th edn, Clinics in Laboratory Medicine. 5th edn. Jakarta: International Labour Organization.

Irawan, F. (2011) Penerapan Ringkas, Rapi, Resik, Rajin (5R) di Bagian Produksi dan Administrasi PT. Calvari Abadi Unit Precast Concrete. Undergraduate Thesis. Surabaya: Faculty of Public Health, Universitas Airlangga.

Istianti, J. (2008) Penerapan 5R Sebagai Salah Satu Upaya Pencegahan Kecelakaan Kerja di Bagian Produksi PT. Bintang Terang Gemilang Sidoarjo. Undergraduate Thesis. Surabaya: Faculty of Public Health, Universitas Airlangga.

Kilpatrick, J. D. (2003) Lean Principles. Utah: Manufacturing Extension Partnership.

Ministry of Manpower and Transmigration (2003) Undang-undang Republik Indonesia No. 13 Tahun 2003 tentang Ketenagakerjaan. Jakarta: Kementerian Tenaga Kerja dan Transmigrasi.

National Social Security (2016) Jumlah Kecelakaan Kerja di Indonesia Masih Tinggi, National Social Security.

Notoatmodjo, S. (2003) Pendidikan \& Perilaku Kesehatan. Jakarta: PT. Rineka Cipta.

Notoatmodjo, S. (2007) Kesehatan Masyarakat Ilmu dan Seni. Jakarta: PT. Rineka Cipta.

Osada, T. (1995) Sikap Kerja 5S. Edited by M. Gandamihardja. Jakarta: Pustaka Binaman Pressindo.

Pranasution, D. (2015) 'Analisis Penerapan Metode 5r (Ringkas, Rapi, Resik, Rawat, Rajin) Di PT Bakrie Pipe Industries Melalui Pendekatan Change Management', Jurnal Ilmiah Universitas Bakrie, 3(3), pp. 1-2.

Rahmatullah, B.(2015)HubunganAntara Karakteristik Individu dengan Tingkat Pengetahuan Penerapan Globally Harmonized System (Studi Kasus di
Unit Amoniak PT. Petrokimia Gresik). Final Project. Surabaya: Faculty of Vocational Studies, Universitas Airlangga.

Rochmanto, D. P. (2015) Penerapan Ringkas, Rapi, Resik, Rawat dan Rajin (5R) dalam Upaya Pengendalian Kebakaran di Unit Produksi 2 PT. Kutai Timber Indonesia (KTI). Undergraduate Thesis. Jember: Faculty of Public Health, Universitas Jember.

Sandika, O. D. (2013) ) Implementasi Budaya 5R (Ringkas, Rapi, Resik, Rawat, Dan Rajin) di Unit Machinery and Tool (UMT) PT. Mega Andalan Kalasan. Undergraduate Thesis. Surakarta: Faculty of Teacher Training and Education, Universitas Sebelas Maret.

Septaviani, R. (2012) Faktor-Faktor yang Berhubungan dengan Praktik 5S (Seiri, Seiton, Seiso, Seiketsu, Shitsuke) pada Mekanik Bengkel Sepeda Motor X Kota Semarang. Undergraduate Thesis. Semarang: Faculty of Public Health Universitas Diponegoro.

Setyanto, G. E. (2015) Analisis Penerapan 5R pada Bagian Produksi di PT. Maritim Barito Perkasa. Undergraduate Thesis. Surabaya: Faculty of Public Health, Universitas Airlangga.

Sugiyono (2013) Metode Penelitian Kuantitatif, Kualitatif dan Kombinasi (Mixed Methods). Bandung: Alfabeta.

Suma'mur (1994) Keselamatan Kerja dan Pencegahan Kecelakaan. Jakarta: Gunung Agung.

Suma'mur (2009) Higiene Perusahaan dan Kesehatan Kerja. Jakarta: Gunung Agung.

Wulansari, Y. P. (2009) Penerapan Program 5R sebagai Upaya Pencegahan Kecelakaan Kerja di Boiler dan Turbin Unit 7 PT. IPMOMI-PAITON Energy Probolinggo. Undergraduate Thesis. Surabaya: Faculty of Public Health, Universitas Airlangga. 